\title{
Effects of the clear-cutting of a Douglas-fir (Pseudotsuga menziesii (Mirb.) Franco) plantation on chemical soil fertility
}

\author{
Jacques RANGER $^{1 *}$, Pascal BonNAUd ${ }^{1}$, Olivier Bouriaud ${ }^{2}$, Dominique GELHAYE $^{1}$, \\ Jean-François PICARD ${ }^{2}$
}

${ }^{1}$ UR Biogéchimie des Écosystèmes Forestiers, INRA Centre de Nancy, 54280 Champenoux, France

${ }^{2}$ UMR Écophysiologie et Écologie Forestières, INRA Centre de Nancy, 54280 Champenoux, France

(Received 14 March 2007; accepted 25 October 2007)

\begin{abstract}
-
- Stand harvesting and regeneration were usually considered to be a critical phase for the sustainability of forest soils. The present study concerned the effects on soil chemical fertility of the clear-cutting of a highly productive Douglas-fir stand aged 67 years that was clear-cut with no disturbance.

- Results showed that soil changes were rapid in the three-year period following the cutting. The forest floor mass considerably decreased and the mineral soil showed a limited but real acidification. Soil losses represented $4 \%$ of the available nutrients over a depth of $60 \mathrm{~cm} \mathrm{for} \mathrm{N,} 22 \%$ for $\mathrm{K}$, $25 \%$ for $\mathrm{Ca}$ and $32 \%$ for $\mathrm{Mg}$. Only $\mathrm{P}$ increased by $11 \%$. Due to the spatial variability of forest soils, and despite regular re-sampling, confidence intervals were large and difficult to reduce.

- The reversibility of the effects of the clear-cutting and its consequences on soil functions depend on the element: it should not be a problem for $\mathrm{C}$, $\mathrm{N}$ and $\mathrm{K}$, which would recover when the biological cycle is re-established once again in the young stand. Phosphorus is not at issue since it changes form in the soil. The depletion of $\mathrm{Ca}$, and to a lesser extent of $\mathrm{Mg}$, is of some concern as a result of limited soil reserves, the limited flux of cations from the mineral changes in the soil, the relatively large part of $\mathrm{Ca}$ and $\mathrm{Mg}$ in the forest floor, and the negative input-output budgets for those elements.

- The duration of the impact of the clear-cutting on soil requires medium-term observations because it cannot be deduced from the current knowledge of this ecosystem.
\end{abstract}

clear-cutting / Douglas-fir / soil fertility / acidification

Résumé - Effets de la coupe à blanc d'un peuplement de Douglas (Pseudotsuga menziesii (Mirb.) Franco) sur la fertilité chimique du sol. - La récolte des peuplements est une phase critique pour la durabilité des sols forestiers. Cette étude concerne les effets de la coupe à blanc d'un peuplement de Douglas de 67 ans, réalisée sans perturbation, sur la fertilité organo-minérale du sol.

- Les résultats montrent que l'évolution du sol est rapide dans la période de trois ans après la coupe. La couche organique décroît fortement et le sol minéral se désature et s'acidifie. Les pertes représentent $4 \%$ des éléments disponibles du sol sur $60 \mathrm{~cm}$ pour N, $22 \%$ pour K, $25 \%$ pour Ca et $32 \%$ pour $\mathrm{Mg}$. Seul P augmente de $11 \%$. Cependant, la variabilité spatiale des sols forestiers et la technique de l'observatoire, par échantillonnages successifs, conduisent à des intervalles de confiance larges autour de ces valeurs, intervalles qui s'avèrent difficile à réduire.

- La réversibilité des modifications du sol dépend des éléments : elle ne devrait pas poser de problème pour $\mathrm{C}, \mathrm{N}$ et $\mathrm{K}$. $\mathrm{P}$ n'est pas en cause puisqu'il change de forme dans le sol mais aucune perte n'est notée. Les pertes de Ca voire de $\mathrm{Mg}$ sont les plus préoccupantes en raison des faibles réserves du sol, du flux limité de cations issu de l'altération des minéraux du sol, de la part relativement élevée des ces éléments dans les couches organiques, et de leur bilan entrées-sorties négatif.

- La durée de l'effet de la coupe à blanc nécessite des observations sur le moyen terme car elle ne peut pas être déduite des connaissances actuelles sur cet écosystème.

coupe à blanc / Douglas / fertilité minérale / acidification

\section{INTRODUCTION}

Soil fertility is not a completely renewable resource, and many French forest soils have low nutrient reserves [4]. All management strategies that do not respect an equilibrium between inputs and outputs in an ecosystem will lead to nutrient depletion [17] and to considerable modifications of all soil functions in the future, including ecological and environmental ones, as well as production [32].

\footnotetext{
*Corresponding author: ranger@nancy.inra.fr
}

Harvesting involves major changes in the soil and the ecosystem because of: (i) the extraction of nutrients from the site at the time of harvest; (ii) changes in the soil climate in terms of temperature and water regime; and (iii) changes in soil biology due to the disruption of biological cycles [34]. These changes are thought to be detrimental to the ecosystem because they lead to intensive decomposition of soil organic matter [36]. Moreover, they increase the nutrient supply to the soil and potential losses via drainage water when the vegetation is not able to absorb them [28]. Nutrient budgets need to be calculated for the entire forest production cycle, including 
the harvesting and regeneration phases, in order to quantify the overall net drain.

In the present study, the rotation phase was observed in an adult Douglas-fir plantation previously monitored for six years [40]. The soil solid phase was observed before the stand was harvested and for the three years following the clearcutting. A diachronic approach was chosen to avoid the effect of soil spatial variability, in a non-replicated experiment.

The present study concerns the changes in the soil phase related to clear-cutting. The hypothesis tested was that very low soil disturbance during harvesting operations would lead to minimal changes in the soil chemistry.

\section{MATERIAL AND METHODS}

\subsection{Study site}

The study site was located in the Monts du Beaujolais, France, $\left(46^{\circ} 30^{\prime} \mathrm{N}, 4^{\circ} 38^{\prime} \mathrm{E}\right)$ at an altitude of $750 \mathrm{~m}$. The mean annual temperature was $7^{\circ} \mathrm{C}$ and the mean annual rainfall was approximately $1000 \mathrm{~mm}$.

A chrono-sequence of three stands, aged 20, 40 and 60 years in 1992 was chosen to represent the total stand development. The variability between years was studied for six years [40]. The 66year-old Douglas-fir stand (Pseudotsuga menziesii (Mirb.) Franco) was clear-cut in October 1998 and planted again with Douglas-fir in March 1999. The stand characteristics before the clear-cutting (autumn 1998) were: 206 trees per ha; an average height of $40 \mathrm{~m}$; a mean diameter at breast height (DBH) of $53 \mathrm{~cm}$. The ground vegetation, dominated by Rubus fruticosus L., Senecio nemorensis F., Rubus idaeus and Digitalis purpurea L., had a biomass of $2.8 \mathrm{tha}^{-1}$.

The soil is of the Alocrisol type [6], and developed from the weathering of an old volcanic tuff from the Visean period. The soil texture was loamy. The humus was of the moder type. The carbon and nitrogen content of the upper soil horizon was relatively high $(4.1 \%$ of $\mathrm{C}$ and $0.37 \%$ of $\mathrm{N}$ in the $\mathrm{A}_{1}$ horizon). The soil was acidic with a $\mathrm{pH}$ ranging from 4.3 to 4.6 from upper $\left(\mathrm{A}_{1} 0-10 \mathrm{~cm}\right)$ to lower horizons $(\mathrm{C} 100 \mathrm{~cm})$. Alkaline and alkaline earth cation saturation was low (15\% in $A_{1}$ and then around 10). A complete soil description and its characteristics are provided by Marques and Ranger [29].

\subsection{Stand manipulation}

The stand was clear-cut while maintaining all the measurement systems, e.g., lysimeters, moisture and temperature probes. The work was done with very limited disturbance to the soil, including the forest floor. Slash was manually windrowed outside the experimental plot (0.5 ha). Vegetation was manually controlled only once a year after the felling operation, in the immediate vicinity of the young Douglas-fir seedlings planted in the spring of 1999.

\subsection{Soil sampling}

Thirty-two soil profiles, distributed on an L-shape grid at regular intervals of approximately $3 \mathrm{~m}$ by $3 \mathrm{~m}$, were sampled in September 1998 before harvesting the stand, and in the same month for three years following the clear-cutting. Destructive sampling involved a systematic calibrated shifting of the sampling place from the initial location.

Samples were collected at various depths: total forest floor, 0$5 \mathrm{~cm}, 5-10 \mathrm{~cm}, 10-15 \mathrm{~cm}, 15-30 \mathrm{~cm}, 30-45 \mathrm{~cm}, 45-60 \mathrm{~cm}$. As for the forest floor, sampling of organo-mineral layers was carried out with a square stainless steel frame buried $15 \mathrm{~cm}$ deep into the ground; below $15 \mathrm{~cm}$, samples were collected using a calibrated soil corer. All the samples (except for the forest floor) were collected on a volume basis.

\subsection{Analytical procedures}

- The forest floor samples were oven-dried at $65^{\circ} \mathrm{C}$, weighed and finely ground for the analysis. The total nutrient contents $(\mathrm{P}, \mathrm{K}, \mathrm{Ca}$, $\mathrm{Mg}, \mathrm{S}, \mathrm{Mn}$ ) were determined on individual samples by ICP spectrophotometry (Jobin-Yvon JY 180 Ultrase) after acid digestion in $\mathrm{H}_{2} \mathrm{O}_{2}+\mathrm{HClO}_{4}$. The total amount of $\mathrm{N}$ was determined by colorimetry using a TRAACS micro-flow analyser, after Kjeldahl digestion.

- The soil samples were oven-dried at $40{ }^{\circ} \mathrm{C}$, then sieved $(2 \mathrm{~mm})$ to separate fine earth from coarse particles, and both were finally weighed separately. The bulk density of the coarse phase was measured by water displacement, and the bulk density of the fine earth was then calculated for each soil sample in order to quantify the nutrient reserve.

- Soil chemical analysis: the $\mathrm{pH}$ was measured in water and in $1 \mathrm{~N}$ $\mathrm{KCl}$ (soil/solution ratio: 1:2.5 w/w). Organic carbon was measured by the Anne method [3], organic-N by the Kjeldahl method, and available phosphorus by the Duchaufour and Bonneau method [16]. Exchangeable elements were extracted by $1 \mathrm{~N} \mathrm{KCl}\left(\mathrm{Ca}^{2+}, \mathrm{Mg}^{2+}, \mathrm{Mn}^{2+}\right.$, $\mathrm{Fe}^{2+}, \mathrm{Na}^{+}$and $\left.\mathrm{Al}^{3+}\right)$ or by $1 \mathrm{~N} \mathrm{NH}_{4} \mathrm{Cl}\left(\mathrm{K}^{+}\right)$[41]. Measurements were made in each replicate, except for $\mathrm{P}$, which was only measured in half of the samples collected in 2001 (results were expressed relative to dry matter at $105^{\circ} \mathrm{C}$ ).

\subsection{Quality control for soil analysis}

To estimate the changes caused by the clear-cutting as accurately as possible, the soil samples were analysed each year by the same operators using the same method and the same equipment. Quality control was performed: (i) by using replicates for each group of analyses validating each series individually; and (ii) by re-analysing a set of samples initially analysed the year following the sampling for some key parameters, after a three-year-storage period, together with the last sample set. This type of comparison cumulates the effects of analysis reliability and reproducibility, and those of sample storage. The results were used to calculate the confidence intervals of determinations in order to evaluate significant soil changes.

Eleven soil profiles evenly distributed over the sampling grid were re-analysed (66 samples) for cation exchange capacity (CEC) and exchangeable cations. An analysis of variance was performed to compare the results and to calculate the intervals of confidence of the mean values. Due to material constraints, comparisons were only made between samples collected in 2001 and samples collected in 1998 before the clear-cutting, and analysed both in 1998 and 2001 for replicates.

The results presented in Table I indicate a very good agreement between the two sets of measurements. Significant differences only occurred for $\mathrm{Al}$ measured by ICP, $\mathrm{H}, \mathrm{Mn}_{\text {exch }}$ and $\mathrm{Na}_{\text {exch }}$. 
Table I. Comparison between measurements made in 1998 (Meas. 98) and in 2001 (Meas. 01) on the same samples collected in 1998 (data in $\mathrm{cmol}_{C} \cdot \mathrm{kg}^{-1}$ for fine earth oven-dried at $\left.105^{\circ} \mathrm{C}\right)$.

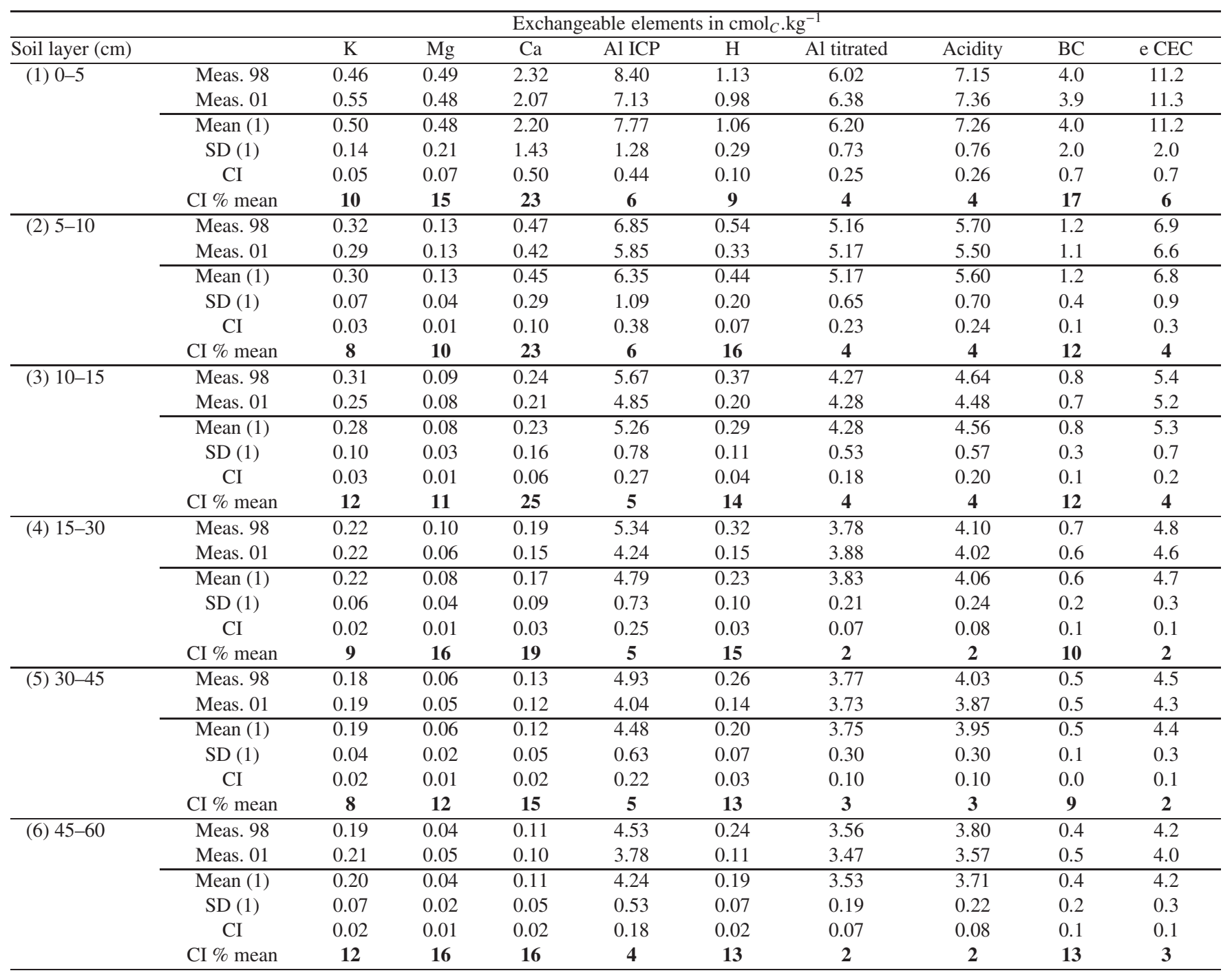

$\mathrm{BC}=$ Sum of exch. $\mathrm{K}, \mathrm{Ca}, \mathrm{Mg}, \mathrm{Na} ;$ eCEC = Effective CEC $;$ Meas. = measurements; SD : square deviation ; CI : confidence interval.

If measurement alone cannot explain the changes because of the presence of internal calibration, storage could be at the origin of changes, as previously demonstrated by Blake et al. [10]. No specific changes were detected for the organic or mineral layers. However, $\mathrm{H}$ decreased, probably indicating that it reacted with the solid phase. $\mathrm{Al}$ measured by ICP decreased by about $1 \mathrm{cmol}_{\mathrm{c}} \cdot \mathrm{kg}^{-1}$, while titrated $\mathrm{Al}$ was remarkably stable. This may indicate that the relatively shortterm storage induced polymerisation of exchangeable Al, which did not affect its titrable part. The increase in manganese (by less than $0.05 \mathrm{cmol}_{\mathrm{c}} \cdot \mathrm{kg}^{-1}$ ) was generally attributed to the re-equilibration of Mn species during the first weeks of natural air-drying [8]. Sodium changes were generally attributed to 'contamination' during laboratory treatments [10].

Two possibilities arose: (i) first, the case of elements usually classified as sensitive to changes during storage ( $\mathrm{Mn}, \mathrm{H}, \mathrm{Al}$ ?), for which the only way of working was to accept changes over time; and (ii) second, the case of elements not sensitive to changes during storage, whose re-analysis provides the limits for an interpretation of the changes.

\subsection{Validity of the measurements}

The test for reproducibility of concentrations made on 11 soil profiles was extrapolated to 32 profiles because the variability covered by the 11 profiles was of the same order as the total variability for the 32 profiles (data not shown). Confidence intervals for the 32 profiles were then calculated using the square deviation for the replicated 11 profiles with the following formula:

$$
x \pm \frac{t \cdot S D}{\sqrt{n}}
$$

where $t$ is the Student $t$ value depending on the degree of freedom, $S D$ the square deviation, and $n$ the number of observations. 
For elements that are usually not sensitive to storage, the part of variability associated with the analytical deviation could be calculated and deduced from the total variability observed. This was done considering a simple additive model, where total variance observed $\left[\Delta\left(2001_{01}-1998_{98}\right)\right]=$ changes due to clear-cutting + analytical uncertainty [IC 199898-01]. Changes lower than the repeatability [IC 1998-01-01] were not considered.

To quantify the soil nutrient reserves, we used the sample volume, the percentage of fine earth (particle size $<2 \mathrm{~mm}$ ), the bulk density and the chemical analysis of fine earth for each sampling point. The bulk density of fine earth was measured in three out of the four sampling times in the upper $15 \mathrm{~cm}$, and in two sampling times in deeper layers. The time variation was quite low and not significant in the upper layers, but larger (about 20\%) and significantly different between the two measurements in deeper soil layers (Tab. IV). The difference in soil moisture at sampling time may have indirectly influenced the observations in the deep layers [30]. The percussion coring method that was used may have led to some compaction when the soil moisture was higher. The mean value for the whole set of samples was used in the calculation, and no temporal variation of physical soil properties was considered. Since no machinery was used in the experiment, we believe that it is reasonable not to consider any physical change.

Confidence intervals of the difference between years were calculated according to the following formula:

$$
\Delta=x_{1}-x_{2} \pm t_{95 \%} \sqrt{\frac{S D_{1}^{2}+S D_{2}^{2}}{n}}
$$

where $t_{95 \%}$ is the value of the Student coefficient for an error risk of $5 \%$ and a degree of freedom equal to $n-1$ observations, and where $x_{1}$, $x_{2}$ and $S D_{1}$ and $S D_{2}$ are the mean and square deviation, respectively, for years 1 and 2 .

\subsection{Data analysis}

An analysis of variance was performed to compare the concentration of elements between the different sampling times using Unistat software (Student-Newmans-Keuls tests were applied at 5\% significance).

A specific treatment of the data, based on the theory of regionalised variables [49], was used with three objectives: (i) to identify a possible spatial structure in the distribution of the value of the variable; (ii) to apply the most accurate variance analysis according to the results obtained; and (iii) to check the possibility of reducing the sample number because of the cost of such an analysis. The analysis of spatial variability relies on the computation of the semi-variogram sample. A semi-variogram is an average measurement of the change of an attribute, referred to as a regionalised variable, according to the scale used. It breaks down the spatial variability of observed variables into distance classes [27]. The empirical semi-variogram at the distance $d$ is defined as:

$$
\gamma(d)=\frac{1}{2 N(d)} \sum_{i=1}^{N(d)}\left[Z\left(x_{i}\right)-Z\left(x_{i}+d\right)\right]^{2}
$$

where $(d)$ is the empirical semi-variance at the distance $d, N(d)$ is the number of pairs at the distance $d$, and $Z\left(x_{i}\right)$ is the observed attribute at the location $x i$. Before the variogram computation, a multiple regression analysis was made to verify the assumption of the spatial stationarity of variables (absence of spatial trend, known as intrinsic stationarity); $E\left[\left(Z\left(x_{i}+d\right)-Z\left(x_{i}\right)\right)^{2}\right]$ does not depend on $x_{i}$ but only on $d$. The aim of detrending is to appropriately model the data in order to estimate the underlying random distribution process. Statistical computations were implemented on S-plus software (S-plus for Unix version 3.0, Statistical Sciences Division, Mathsoft Inc., Seattle, WA, USA) using the "S + Spatial Stats Module". Maps were created with Golden Software Surfer 7.0 (Golden Software, Inc.).

\section{RESULTS}

\subsection{Spatial structure of the variation of soil characteristics}

Empirical semi-variograms were drawn after verifying the stationarity test for variables. In most cases, the semi-variance almost reached the maximum value observed at the first distance class: no semi-variance increment with increasing distance between points was observed. In other words, the average variance between close points was comparable to that of distant points, since it did not depend on the distance between them. Examples for $\mathrm{C}_{\text {org }}$ and Norg are presented in Figure 1. It was impossible to conclude that there was no spatial structure of the studied variables because the number of points included may have been insufficient to reveal such a process. However, it can be established that no autocorrelation existed in the data set because each plot provided new information, and because the precision of estimation depended on the number of plots included but not on their location. This result was demonstrated for distances of less than $50 \mathrm{~m}$. Since no geographical structure of the data set was observed, a sub-sampling (systematic as well as random) is allowed. A classical comparison of paired variables for analysis of variance was therefore used.

\subsection{Effect of the clear-cutting on soil characteristics}

- Forest floor: before the clear-cutting, the forest floor mass consisted of about $41 \mathrm{t}^{\mathrm{th}} \mathrm{h}^{-1}$ of dry matter. It contained $17 \mathrm{t}$ of C, $619 \mathrm{~kg}$ of N, $43 \mathrm{~kg}$ of P, $85 \mathrm{~kg}$ of K, $228 \mathrm{~kg}$ of Ca and $59 \mathrm{~kg}$ of $\mathrm{Mg}$ per ha. One year after the clear-cutting, the dry matter mass and the nutrient content had not changed (except for $\mathrm{Mg}$ ). In 2000 and 2001, the forest floor mass and its nutrient content considerably declined (Tab. II), but without any significant changes in the nutrient concentrations, which tended to recover their initial values with the notable exception of $\mathrm{Ca}$ (Tab. III). During this period, C concentration decreased constantly, indicating that some mineral material was integrated into the forest floor, which considerably diminished in thickness.

- Organo-mineral soil layer: concentrations and statistical significance of differences between the four sampling dates are presented in Tabl. IV. One year after the clear-cutting, changes were generally small. However, they were significant for some elements e.g., $\mathrm{K}_{\text {exch }}, \mathrm{Al}_{\text {exch }}$, available $\mathrm{P}$, and to a lesser extent for $\mathrm{Mg}_{\text {exch }}, \mathrm{H}_{\text {exch }}$ and $\mathrm{C}_{\text {org. }}$. In the upper layers [0 to $10 \mathrm{~cm}$ ], changes were limited; ICP- $\mathrm{Al}_{\text {exch }}$ decreased, whereas $\mathrm{C}_{\text {org }}$ and 

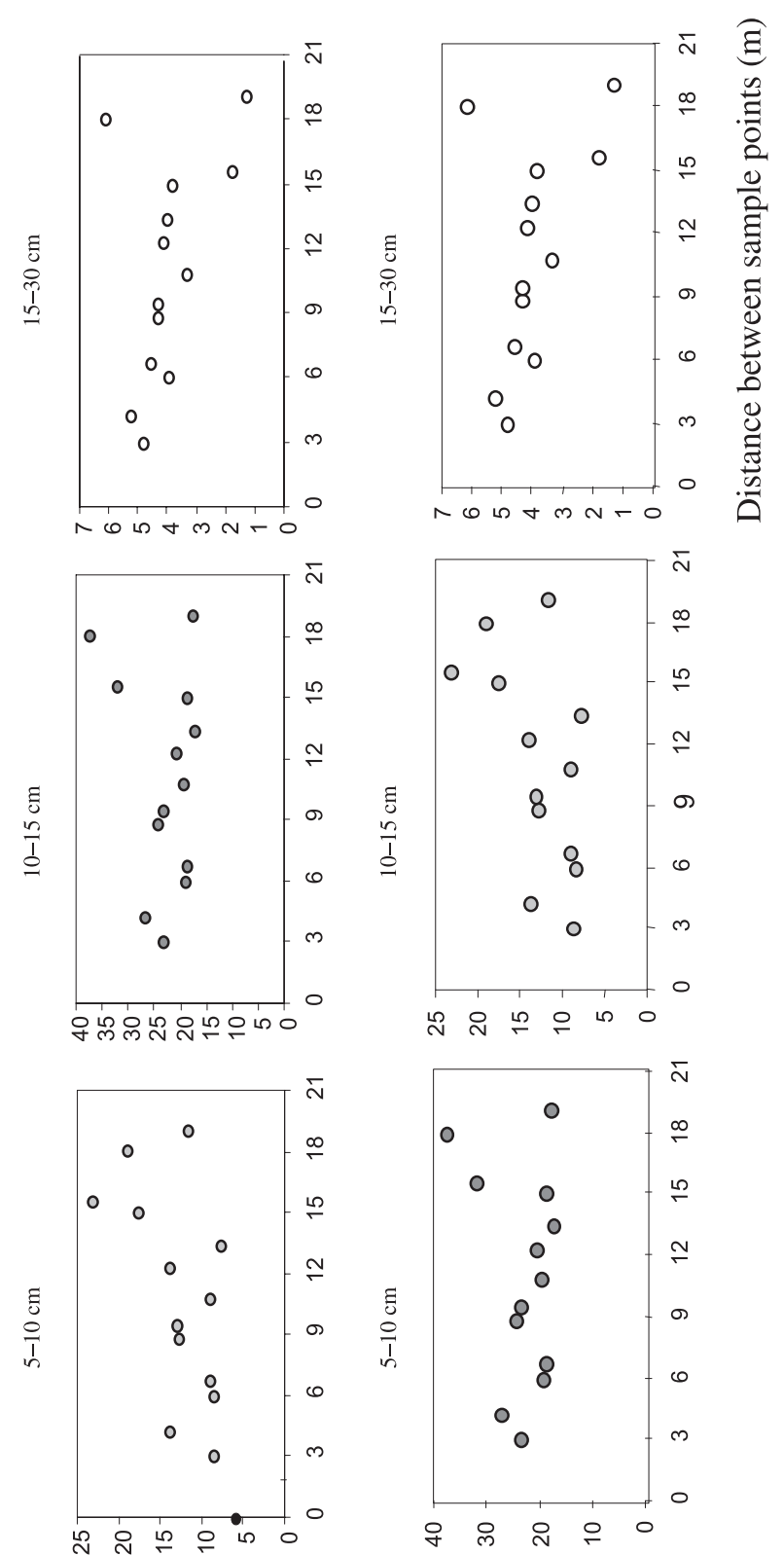

뉴 은으 ᄂ
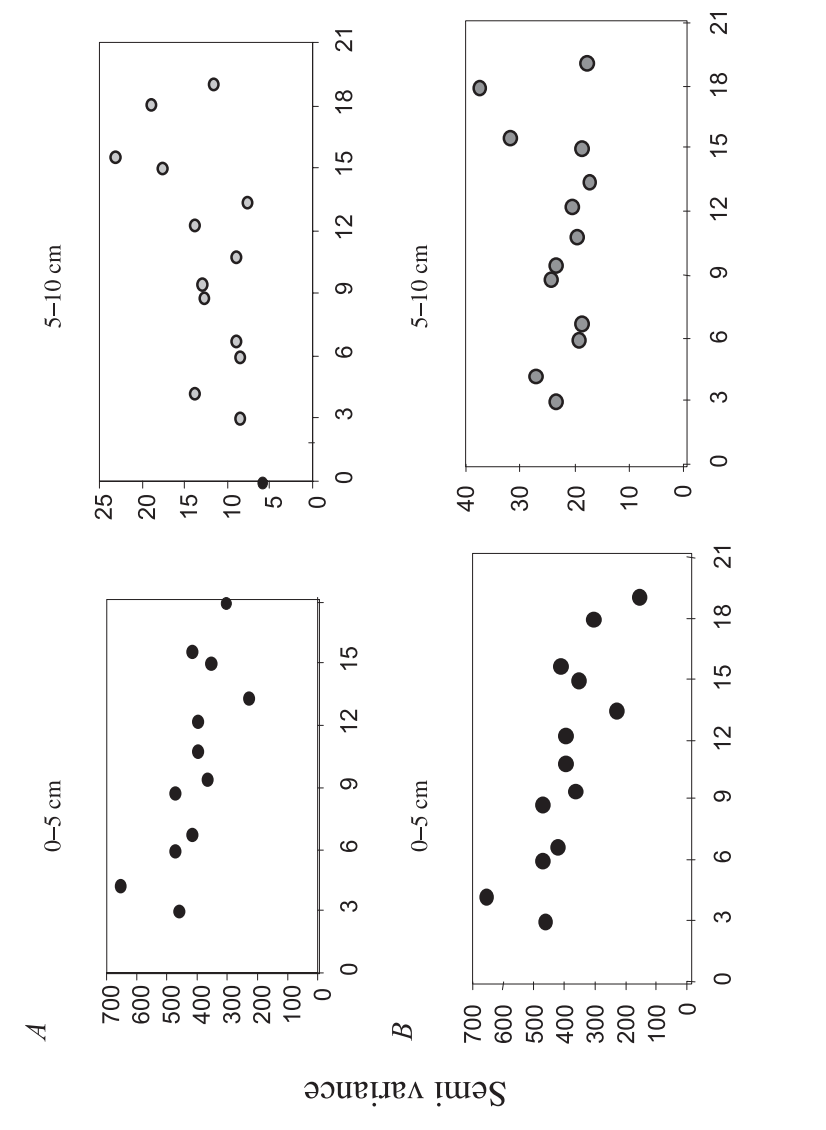
Table II. Carbon and nutrient content in the forest floor before (BC-F) and for three years following clear-felling (AC-F) (DM is dry matter at $\left.65^{\circ} \mathrm{C}\right)$.

\begin{tabular}{|c|c|c|c|c|c|c|c|c|}
\hline & & $\overline{\mathrm{DM}}$ & $\mathrm{C}$ & $\mathrm{N}$ & $\bar{P}$ & $\bar{K}$ & $\mathrm{Ca}$ & $\mathrm{Mg}$ \\
\hline & & \multicolumn{2}{|c|}{ t.ha ${ }^{-1}$} & \multicolumn{5}{|c|}{$\mathrm{kg}^{\mathrm{h} \mathrm{ha}^{-1}}$} \\
\hline $\mathrm{BC}-\mathrm{F}$ & Square deviation & 10.3 & 5.7 & 178.1 & 12.1 & 32.0 & 79.1 & 20.5 \\
\hline AC-F & Square deviation & 16.9 & 6.9 & 227.4 & 16.2 & 33.5 & 110.9 & 21.1 \\
\hline 2000 & Mean & $28.2 \mathrm{~b}$ & $8.3 \mathrm{~b}$ & $355.4 \mathrm{~b}$ & $24.3 \mathrm{ab}$ & $46.5 \mathrm{~b}$ & $127.3 \mathrm{~b}$ & $40.0 \mathrm{~b}$ \\
\hline AC-F & Square deviation & 10.8 & 3.0 & 123.7 & 9.0 & 20.2 & 49.7 & 17.8 \\
\hline
\end{tabular}

A different letter for a same element indicates significant differences between dates at $p>0.05$.

Table III. Carbon and nutrient concentration in the forest floor before (BC-F) and for three years following clear-felling (AC-F) (DM is dry matter at $65^{\circ} \mathrm{C}$ ).

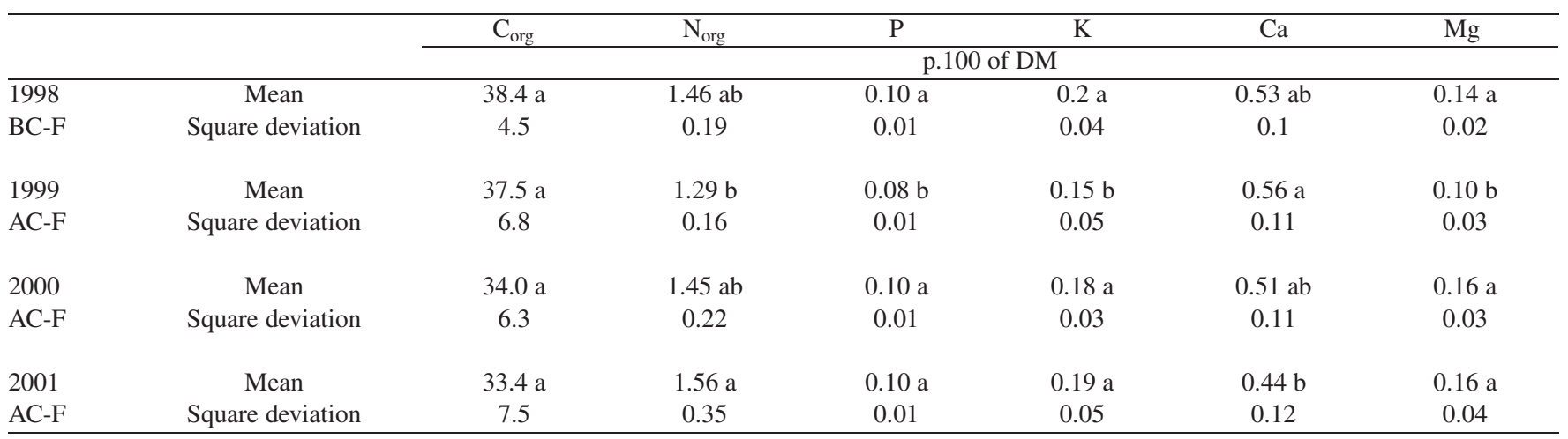

A different letter for a same element indicates significant differences between dates at $p>0.05$.

$\mathrm{P}$ increased. In the middle and bottom layers, $\mathrm{K}_{\text {exch }}, \mathrm{Mg}_{\text {exch }}$, ICP-Al $1_{\text {exch }}$ and $\mathrm{H}_{\text {exch }}$ decreased, while available $\mathrm{P}$ increased. $\mathrm{CEC}$ and $\mathrm{pH}_{\mathrm{H} 2 \mathrm{O}}$ did not change; $\mathrm{pH}_{\mathrm{KCl}}$ significantly decreased by 0.05 to $0.1 \mathrm{pH}$ in the middle layers, as was the case for $\mathrm{C}_{\text {org }}$ and $\mathrm{N}_{\text {org }}$ in the bottom layer.

Two years after the clear-cutting, $\mathrm{K}_{\text {exch }}, \mathrm{Ca}_{\text {exch }}, \mathrm{Mn}_{\text {exch }}$, titrable $\mathrm{Al}_{\text {exch }}$, eCEC, $\mathrm{C}_{\text {org }}$, and $\mathrm{N}_{\text {org }}$ concentrations increased to their maximum levels in the upper layers [0-10 cm], and the increase was even more obvious in the 0-5 cm layer. $\mathrm{H}_{\mathrm{exch}}$ decreased, $\mathrm{pH}_{\mathrm{H} 2 \mathrm{O}}$ increased, and available $\mathrm{P}$ recovered its initial values. Changes were more linear in the deeper soil layers with a decrease in $\mathrm{K}_{\text {exch }}, \mathrm{Ca}_{\mathrm{exch}}, \mathrm{Mg}_{\text {exch }}$, 'base' cation saturation, $\mathrm{H}_{\text {exch }}$ and ICP $\mathrm{Al}_{\text {exch }}$; eCEC did not change, $\mathrm{P}$ recovered its initial level, $\mathrm{C}_{\text {org }}$ and $\mathrm{N}_{\text {org }}$ decreased but only significantly at a depth of $45-60 \mathrm{~cm}$, and $\mathrm{pH}_{\mathrm{H} 2 \mathrm{O}}$ and $\mathrm{pH}_{\mathrm{KCl}}$ increased by 0.1 to $0.3 \mathrm{pH}$ units.

Three years after the clear-cutting, the changes confirmed the tendencies identified after two years, but some parameters such as CEC or $\mathrm{pH}$ tended to recover their initial values.

These observations are summarised in Table $\mathrm{V}$ in terms of changes relative to the situation before the clear-cutting. The interval of confidence of the values is based on the re-analysis of samples collected in 1998 and in 2001 [IC 199898-01].

\subsection{Element reserves in soil layers}

The dynamics of soil changes after the clear-cutting depended both on the concentration changes and the spatial variability of the bulk density because no time change was considered for the bulk density in our study. For the period 1998-2001, the results presented in Table VI show a significant increase in organic $\mathrm{C}$ and $\mathrm{N}$, available $\mathrm{P}$, and in exchangeable $\mathrm{K}$ and $\mathrm{Mg}$ in the $0-5 \mathrm{~cm}$ layer. Upon reaching the $5-10 \mathrm{~cm}$ layer, this trend persisted for $\mathrm{C}_{\text {org }}$ and available $\mathrm{P}$, but not for the other elements that decreased; nevertheless, confidence intervals were too large for significant changes. In the deeper soil layers, the change tended towards a decrease in $\mathrm{K}, \mathrm{Ca}$ and $\mathrm{Mg}$ content (always significant for $\mathrm{K}$ and $\mathrm{Mg}$, but only significant for $\mathrm{Ca}$ in the 30 to $60 \mathrm{~cm}$ layers), an increase in exchangeable $\mathrm{Al}$ (only significant in the deepest layer), a decrease in $\mathrm{N}_{\text {org }}$ (only significant in the deepest layer), and an increase in $\mathrm{P}$ (significant from 15 to $60 \mathrm{~cm}$ in depth). Organic $\mathrm{C}$ tended to increase in the medium soil layers $[10-30 \mathrm{~cm}]$ and to significantly decrease in the deepest layer [45-60 cm].

The dynamics of these changes during the three years following the clear-cutting were maximal in the upper layers in the second year, whereas they were more gradual in the rest of the soil profile. 


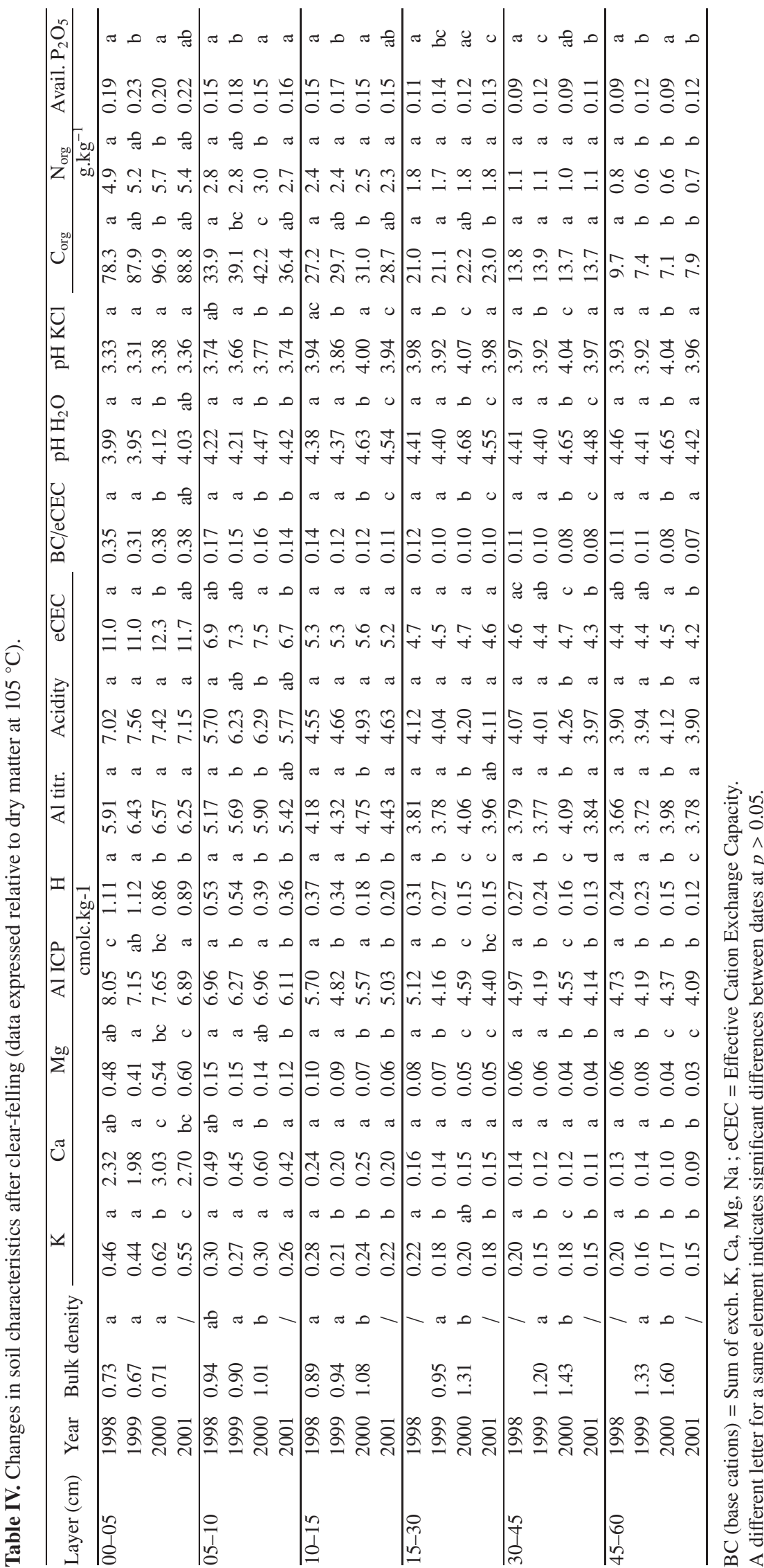


Table V. Relative changes in soil characteristics comparing the soil before (1998) and three years after clear-felling (2001).

\begin{tabular}{|c|c|c|c|c|c|c|}
\hline \multirow{2}{*}{ Parameter } & \multicolumn{2}{|c|}{ Upper layer } & \multicolumn{2}{|c|}{ Middle layers } & \multicolumn{2}{|c|}{ Deep layers } \\
\hline & $\Delta\left(01_{01}-98_{98}\right)$ & IC 9898-01 & $\Delta\left(01_{01}-98_{98}\right)$ & IC 9898-01 & $\Delta\left(01_{01}-98_{98}\right)$ & IC 9898-01 \\
\hline - Water & Stable & nd & +2 to $+4 \%$ & nd & Stable & nd \\
\hline Carbon & $+13 \%$ & nd & +1 to $+10 \%$ & nd & $-18 \%$ & nd \\
\hline Nitrogen & $+10 \%$ & nd & -2 to $+5 \%$ & nd & $-17 \%$ & nd \\
\hline Phosphorus & $+10 \%$ & nd & +3 to $+30 \%$ & nd & $+28 \%$ & nd \\
\hline$-\mathrm{Ca}$ & $+16 \%$ & $23 \%$ & -5 to $-20 \%$ & 15 to $23 \%$ & $-33 \%$ & $16 \%$ \\
\hline$-\mathrm{Mg}$ & $+26 \%$ & $15 \%$ & -20 to $-35 \%$ & 10 to $16 \%$ & $-38 \%$ & $16 \%$ \\
\hline \multicolumn{7}{|l|}{ Acid cations } \\
\hline$-\mathrm{Al}$ & $+5 \%$ & $4 \%$ & 0 to $+6 \%$ & 2 to $4 \%$ & $+3.5 \%$ & $2 \%$ \\
\hline$-\mathrm{H}$ & $-20 \%$ & $n d$ & -30 to $-50 \%$ & nd & $-52 \%$ & $n d$ \\
\hline
\end{tabular}

$\Delta\left(01_{01}-98_{98}\right)=$ difference between the values observed in $2001(01)$ and 1998 (98) the index correspond to the year of laboratory measurement. IC = Interval of confidence determined on the samples collected analyzed both in 1998 (index 98) and 2001 (index 01).

\section{DISCUSSION}

\subsection{Changes in the forest floor}

Important changes take place in the forest floor (FF) following clear-cutting [21]. In the present study, returns from trees were stopped, no slash remained on the soil, and the understorey vegetation did not produce large amounts of litter because its biomass was limited (4 to $5 \mathrm{t}$ of DM.ha ${ }^{-1}$.year ${ }^{-1}$ consisting of biennial species). More than $55 \%$ of the initial DM (10.2t of $\left.\mathrm{C} \mathrm{ha}^{-1}\right)$ and about the same percentage of $\mathrm{C}$ and nutrients (from $48 \%$ for $\mathrm{Mg}$ to $63 \%$ for $\mathrm{Ca}$ ), which represented $323 \mathrm{~kg} \mathrm{~N}, 23 \mathrm{~kg}$ of $\mathrm{P}, 47 \mathrm{~kg}$ of $\mathrm{K}, 144 \mathrm{~kg}$ of $\mathrm{Ca}$ and $28 \mathrm{~kg}$ of $\mathrm{Mg}$ per ha, had disappeared three years after the clearcutting. The decrease probably continued after the third year when $18 \mathrm{t}$ of DM.ha ${ }^{-1}$ remained, but probably without leading to the complete disappearance of FF because the new Douglasfir plantation was developing quite quickly and the concurrent vegetation was still present, ensuring a complete covering for FF and a new source for litter fall. A test of decomposition of individual slash components using the litter-bag technique was carried out at the site to measure the rate of nutrient restitution. Results showed that about $50 \%$ of needles and $30 \%$ of branches disappeared during the same three years (experiment still going on - Zeller et al., unpublished data).

\subsection{Changes in the mineral soil}

As previously shown in several studies, statistically significant short-term changes in soil characteristics were not easy to identify because of large spatial variations and because of the difficulty of accurately reproducing soil analyses [12]. Nevertheless, there was evidence that soil characteristics were rapidly modified at the study site after the stand was harvested.
Changes concerned both the organically-bound elements such as $\mathrm{C}, \mathrm{N}$ and $\mathrm{P}$, and the mineral exchangeable cations. Observations could be explained by the properties of each element:

- The biodegradability of SOM led to a rapid decrease in $\mathrm{C}_{\text {org }}$ and $\mathrm{N}_{\text {org }}$ in the profile, but part of the organic matter from the forest floor was physically transferred to the upper soil layers.

- Though it was reduced after the clear-cutting, nitrification led to an excess in nitric acid, which was neutralised in ion exchange or weathering reactions, leading to cation losses [26].

- Phosphorus released by the mineralisation of FF and SOM tended to accumulate in the soil profile due to its very low solubility in the drainage water [46].

- The cation exchange capacity (CEC) followed the $\mathrm{C}_{\text {org }}$ fluctuations that increased in the upper layers and decreased in the lower layers. Small changes in soil pH did not lead to significant modifications in $\mathrm{C}_{\text {org }}$ reactivity.

- Alkaline and alkaline earth cations (base cations) reacted very quickly to the cycle changes; they increased in the upper layers and were depleted in the other layers.

Changes in $\mathrm{pH}$ values were rather limited for both water and $\mathrm{KCl}$ measurements. The soil solid phase appeared to be quite well-buffered against changes.

A quantification of the soil reserves showed that part of the material leaving FF was transferred to the mineral soil where organic $\mathrm{C}$ increased by $9.5 \mathrm{tha}^{-1}$ in three years on the upper $30 \mathrm{~cm}$ layers. The other part of the FF material, assumed to be predominant on the basis of other studies, was mineralised to $\mathrm{CO}_{2}$ (from 80 to $95 \%$, according to Berthelin et al., [9]). Soil organic $\mathrm{C}$ also evolved from the root decomposition of the previous stand and from the newly developing understorey, although the root biomass of the understorey was not measured. A rough calculation based on the following parameters - an 
Table VI. Quantitative changes in the soil reserves after the clear-cutting for individual soil layers and for the soil profile over a 60 -cm depth.

\begin{tabular}{|c|c|c|c|c|c|c|c|c|c|c|c|c|c|c|c|c|c|}
\hline \multirow{3}{*}{$\begin{array}{l}\text { Soil layer } \\
00-05\end{array}$} & \multirow{3}{*}{$\begin{array}{c}\text { Year } \\
1998\end{array}$} & \multicolumn{2}{|l|}{$\mathrm{K}$} & \multirow{2}{*}{\multicolumn{2}{|c|}{$\mathrm{Ca}$}} & \multirow{2}{*}{\multicolumn{2}{|c|}{$\begin{array}{l}\mathrm{Mg} \\
\text { kg.ha-1 }\end{array}$}} & \multicolumn{2}{|l|}{$\mathrm{Mn}$} & \multirow[t]{2}{*}{$\mathrm{Al}$} & & \multirow[t]{2}{*}{$\mathrm{C}_{\mathrm{org}}$} & \multicolumn{2}{|r|}{$\mathrm{N}_{\text {org }}$} & & \multicolumn{2}{|c|}{$\mathrm{P}_{2} \mathrm{O}_{5}$} \\
\hline & & & & & & & & & & & & & \multicolumn{2}{|c|}{ t.ha-1 } & & \multicolumn{2}{|c|}{ kg.ha-1 } \\
\hline & & 61.6 & $\mathrm{a}$ & 158.2 & $\mathrm{ac}$ & 19.9 & $a b$ & 42.6 & $\mathrm{ab}$ & 187.1 & $\mathrm{a}$ & 27.03 & $\mathrm{a}$ & 1.71 & $\mathrm{a}$ & 68 & $\mathrm{a}$ \\
\hline & 1999 & 60.7 & $\mathrm{a}$ & 138.4 & $\mathrm{ac}$ & 17.4 & $a b$ & 37.5 & $\mathrm{ab}$ & 203 & $\mathrm{a}$ & 30.71 & $\mathrm{ab}$ & 1.82 & $a b$ & 79 & $\mathrm{a}$ \\
\hline & 2001 & 74.7 & $\mathrm{c}$ & 188.7 & $\mathrm{bc}$ & 25.5 & $\mathrm{c}$ & 46.5 & $a b$ & 197.8 & $\mathrm{a}$ & 31.17 & $a b$ & 1.91 & $a b$ & 77 & $\mathrm{a}$ \\
\hline$\Delta(2001-1998)$ & & 13.1 & & 30.5 & & 5.6 & & 3.9 & & 10.7 & & 4.14 & & 0.2 & & 8 & \\
\hline \multirow[t]{4}{*}{$\overline{05-10}$} & 1998 & 55.9 & $\mathrm{a}$ & 46.1 & $\mathrm{a}$ & 8.5 & $\mathrm{a}$ & 20.2 & $\mathrm{a}$ & 220.3 & $\mathrm{a}$ & 16.04 & $\mathrm{a}$ & 1.31 & $\mathrm{a}$ & 73 & $\mathrm{a}$ \\
\hline & 1999 & 50.5 & $\mathrm{a}$ & 42.5 & $\mathrm{a}$ & 8.6 & $\mathrm{a}$ & 15.9 & $\mathrm{~b}$ & 243.6 & $\mathrm{~b}$ & 18.6 & $\mathrm{bc}$ & 1.35 & $a b$ & 84 & $\mathrm{~b}$ \\
\hline & 2000 & 55 & $\mathrm{a}$ & 56.4 & $\mathrm{~b}$ & 8 & $\mathrm{a}$ & 18.8 & $\mathrm{a}$ & 251.5 & $\mathrm{~b}$ & 19.97 & c & 1.44 & $\mathrm{~b}$ & 71 & $\mathrm{a}$ \\
\hline & 2001 & 47.8 & $\mathrm{a}$ & 39.6 & $\mathrm{a}$ & 6.7 & $\mathrm{~b}$ & 15.2 & $\mathrm{~b}$ & 231.6 & $a b$ & 17.28 & $\mathrm{ab}$ & 1.29 & $\mathrm{a}$ & 76 & $\mathrm{ab}$ \\
\hline$\Delta(2001-1998)$ & & -8.2 & & -6.4 & & -1.8 & & -5 & & 11.3 & & 1.24 & & -0.03 & & 3 & \\
\hline & 1999 & 41 & $\mathrm{~b}$ & 19.9 & $\mathrm{a}$ & 5.6 & $\mathrm{a}$ & 8.5 & $\mathrm{~b}$ & 187.9 & $\mathrm{a}$ & 14.27 & $\mathrm{~b}$ & 1.13 & $\mathrm{a}$ & 81 & $\mathrm{~b}$ \\
\hline & 2000 & 45 & $\mathrm{~b}$ & 23.8 & $\mathrm{a}$ & 4.2 & $\mathrm{~b}$ & 10.8 & $\mathrm{a}$ & 205.8 & $\mathrm{~b}$ & 14.85 & $\mathrm{~b}$ & 1.18 & $\mathrm{a}$ & 70 & $\mathrm{a}$ \\
\hline & \multirow[t]{4}{*}{2001} & 41.6 & $\mathrm{~b}$ & 19.4 & $\mathrm{a}$ & 3.7 & $\mathrm{~b}$ & 7.9 & $\mathrm{~b}$ & 192.7 & $a b$ & 13.78 & $a b$ & 1.1 & $\mathrm{a}$ & 74 & $a b$ \\
\hline$\Delta(2001-1998)$ & & -12.3 & & -4.3 & & -2 & & -4.4 & & 10.9 & & 0.71 & & -0.06 & & 3 & \\
\hline$\Delta(01-98) \%$ & & -22.9 & & -18.2 & & -35 & & -35.7 & & 6 & & 5.46 & & -5.12 & & 4.13 & \\
\hline CI $\Delta(2001-1998)$ & & 8 & & 5.9 & & 0.8 & & 1.9 & & 14.6 & & 1 & & 0.07 & & 10 & \\
\hline \multirow[t]{4}{*}{$\overline{15-30}$} & 1998 & 146.6 & $\mathrm{a}$ & 55 & $\mathrm{a}$ & 16.8 & $\mathrm{a}$ & 30.6 & $\mathrm{a}$ & 579.9 & $\mathrm{a}$ & 35.39 & $\mathrm{a}$ & 2.97 & $\mathrm{a}$ & 190 & $\mathrm{a}$ \\
\hline & 1999 & 121.2 & $\mathrm{~b}$ & 46.1 & $\mathrm{a}$ & 14 & $\mathrm{~b}$ & 19.5 & $\mathrm{~b}$ & 573.8 & $\mathrm{a}$ & 35.53 & $\mathrm{a}$ & 2.85 & $\mathrm{a}$ & 229 & $\mathrm{~b}$ \\
\hline & 2000 & 133.3 & $a b$ & 49.7 & $\mathrm{a}$ & 9.4 & $\mathrm{c}$ & 22.9 & $\mathrm{~b}$ & 615.8 & $\mathrm{a}$ & 37.38 & $\mathrm{a}$ & 2.98 & $\mathrm{a}$ & 200 & $\mathrm{ab}$ \\
\hline & 2001 & 120.1 & $\mathrm{~b}$ & 52.2 & $\mathrm{a}$ & 10.2 & $\mathrm{c}$ & 21.7 & $\mathrm{~b}$ & 601.8 & $\mathrm{a}$ & 38.81 & $\mathrm{a}$ & 3.07 & $\mathrm{a}$ & 220 & $a b$ \\
\hline$\Delta(2001-1998)$ & & -26.5 & & -2.8 & & -6.6 & & -8.9 & & 22 & & 3.42 & & 0.11 & & 30 & \\
\hline$\Delta(2001-1998)$ & & -41.1 & & -11.8 & & -5.4 & & -12 & & -0.4 & & -0.41 & & -0.11 & & 47 & \\
\hline$\Delta(01-98) \%$ & & -26.2 & & -21.7 & & -37.4 & & -35.8 & & -0.1 & & -1.49 & & -5.09 & & 27.43 & \\
\hline CI $\Delta(2001-1998)$ & & 19.7 & & 9.7 & & 2.4 & & 3.8 & & 42.7 & & 3.04 & & 0.24 & & 24 & \\
\hline$\overline{45-60}$ & 1998 & 168.2 & $\mathrm{a}$ & 55.2 & $\mathrm{a}$ & 14.6 & $\mathrm{a}$ & 33.3 & $\mathrm{a}$ & 722.5 & $\mathrm{a}$ & 21.03 & $\mathrm{a}$ & 1.8 & $\mathrm{a}$ & 201 & $\mathrm{a}$ \\
\hline & 1999 & 136.1 & $\mathrm{~b}$ & 60.7 & $\mathrm{a}$ & 21.1 & $\mathrm{~b}$ & 24 & $\mathrm{~b}$ & 731.4 & $\mathrm{a}$ & 16.05 & $\mathrm{~b}$ & 1.4 & $\mathrm{~b}$ & 263 & $\mathrm{~b}$ \\
\hline & 2000 & 144 & $\mathrm{~b}$ & 42.4 & $\mathrm{~b}$ & 9.5 & $\mathrm{c}$ & 21.6 & $\mathrm{~b}$ & 780.9 & $\mathrm{~b}$ & 15.03 & $\mathrm{~b}$ & 1.26 & $\mathrm{~b}$ & 204 & $\mathrm{a}$ \\
\hline & 2001 & 128.7 & $\mathrm{~b}$ & 38.9 & $\mathrm{~b}$ & 9.4 & $\mathrm{c}$ & 20.3 & $\mathrm{~b}$ & 756 & $a b$ & 17.49 & $\mathrm{~b}$ & 1.52 & $\mathrm{~b}$ & 257 & $\mathrm{~b}$ \\
\hline$\Delta(2001-1998)$ & & -39.5 & & -16.3 & & -5.3 & & -13 & & 33.4 & & -3.54 & & -0.28 & & 57 & \\
\hline$\Delta(01-98) \%$ & & -23.5 & & -29.6 & & -36.1 & & -39 & & 4.6 & & -16.84 & & -15.68 & & 28.34 & \\
\hline CI $\Delta(2001-1998)$ & & 18.7 & & 9.8 & & 2.5 & & 3.1 & & 29.6 & & 3.33 & & 0.22 & & 30 & \\
\hline$\overline{\Delta(2001-1998)[0-60 \mathrm{~cm}]}$ & & -115 & & -11 & & -16 & & -39 & & 88 & & 5.56 & & -0.18 & & 148 & \\
\hline CI of changes & & 26.1 & & 31.6 & & 4.1 & & 7.5 & & 123.6 & & 5.04 & & 0.38 & & 40 & \\
\hline Reserves $1998^{1}$ & & 644 & & 393 & & 80 & & 173 & & 2574 & & 140 & & 11 & & 774 & \\
\hline Reserves $2001^{1}$ & & 529 & & 381 & & 65 & & 133 & & 2662 & & 146 & & 11 & & 922 & \\
\hline Changes $\%$ reserves 98 & & -18 & & -3 & & -19 & & -23 & & 3 & & 4 & & -2 & & 19 & \\
\hline
\end{tabular}

${ }^{1}$ Available reserves for all element except $\mathrm{C}$ and $\mathrm{N}$ (total reserves).

A different letter for a same element indicates significant differences between dates at $p>0.05$. 
aboveground to belowground biomass ratio of 1 , a fine root to total root ratio of 0.5 , a fine root turnover of six months, and a mineralisation rate of $\mathrm{C}_{\text {org }}$ of 0.8 - indicated that the contribution of understorey roots could not be greater than $0.5 \mathrm{t}$ of $\mathrm{C} \mathrm{ha}^{-1}$. Measurements made on the 47-year-old Douglasfir stand of the chrono-sequence had shown that the root system represented $18 \%$ of the total stand biomass [37], in other words, $2.1 \mathrm{t} \mathrm{ha}^{-1}$ for fine roots and $4.6 \mathrm{t} \mathrm{ha}^{-1}$ for mediumsized roots whose decomposition after three years was $35 \%$. If we consider that the root system did not change when the stand was 47 to 68 years old, and that big roots and stumps were not significantly decomposed during the three-year period, then the decomposition of tree roots could range from 1.2 to $1.5 \mathrm{t}$ of $\mathrm{C}$, no more than $50 \%$ of which would be integrated into the C-organic pool. This suggests that about $50 \%$ of the FF would have been directly incorporated into the mineral layers, probably by bioturbation. Moreover, speciation of $\mathrm{C}_{\text {org }}$ would probably have shown that clear-cutting may also have affected the quality of SOM; the increase in the $\mathrm{C}: \mathrm{N}$ ratio was an indicator of these changes.

Changes in the mineral soil need to be analysed by layer groups, differentiating between the upper and the lower horizons, and distinguishing between strongly organically-bound elements such as. $\mathrm{C}$ and $\mathrm{N}$, and to a lesser extent, $\mathrm{P}$ and exchangeable mineral elements.

In the uppermost soil layer [0-5 cm], the net enrichment of $\mathrm{C}$ and nutrients mainly resulted from the transfer of material from FF degradation: transfer of OM resulted from physical and biological processes, and transfer of cations occurred in solution. In fact, this enrichment masked an opposite trend linked to a general increase in the turnover rate of soil organic matter due to the physical changes in the soil climate and to the considerable changes in the biological cycle linked to tree harvesting (no more uptake and returns). In the 5-10 cm layer, the compensation for the transfers from the $\mathrm{FF}$ and the quick degradation of SOM led to a stabilisation of $\mathrm{C}_{\text {org }}$ and $\mathrm{N}_{\text {org }}$ and a limited deficit for the nutrient budgets. In deeper layers, the imbalance between these two processes increased, and the budgets became more highly negative. In the deepest layers, $\mathrm{C}_{\text {org }}$ and $\mathrm{N}_{\text {org }}$ tended to decrease, desaturation was considerable, and exchangeable Al increased. Phosphorus displayed a significant increase in the lower layers, indicating that it was released by mineralisation but stayed in the profile because of its very low solubility.

Even with 32 soil profiles being analysed repeatedly, it was difficult to quantify the changes of the mineral soil with high accuracy, as shown by the large confidence intervals of the mean values: $-115 \pm 26 \mathrm{~kg} \cdot \mathrm{ha}^{-1}$ for $\mathrm{K},-11 \pm 32 \mathrm{~kg} \cdot \mathrm{ha}^{-1}$ for $\mathrm{Ca},-16 \pm 4 \mathrm{~kg} \cdot \mathrm{ha}^{-1}$ for $\mathrm{Mg},-176 \pm 375 \mathrm{~kg} \cdot \mathrm{ha}^{-1}$ for $\mathrm{N}$, $+5558 \pm 5040 \mathrm{~kg} \cdot \mathrm{ha}^{-1}$ for $\mathrm{C}$, and $+148 \pm 40 \mathrm{~kg} \cdot \mathrm{ha}^{-1}$ for $\mathrm{P}_{2} \mathrm{O}_{5}$. Changes calculated relative to available soil reserves in 1998 were: $-18 \% \pm 4 \%$ for $\mathrm{K},-3 \% \pm 8 \%$ for $\mathrm{Ca},-19 \% \pm 5 \%$ for $\mathrm{Mg},+19 \pm 5 \%$ for $\mathrm{P},+4 \% \pm 4 \%$ for $\mathrm{C}$, and $-1.5 \% \pm 3 \%$ for $\mathrm{N}$, relative to total organic reserves.

Budgets calculated for the soil, for forest floor, for organomineral layers or for the total $60-\mathrm{cm}$ depth indicated that soil changes were relatively large, both in absolute and relative values. Considering the short period following the clear- cutting, this indicates rather drastic changes. Soil temperature and soil moisture increased after the clear-cutting [19], leading to a noteworthy but short increase in the soil microbial biomass [42]. The forest floor considerably decreased but the mineral soil recovered part of this mass as organic $\mathrm{C}$. The $\mathrm{C}$ budget indicated a net loss of $10.2{\mathrm{t} . \mathrm{ha}^{-1}}$ for FF and a net gain of $5.6 \mathrm{t}^{-h^{-1}}$ in the mineral soil, which corresponded to a net loss of $4.6 \mathrm{t}^{\mathrm{h} \mathrm{ha}^{-1}}$ of organic $\mathrm{C}$ for the overall soil. The flux of cations released by the weathering of soil minerals measured at the site during the previous forest production cycle indicated a limited capacity of the soil to restore its natural fertility. The estimation of the weathering flux was only $7.5 \mathrm{~kg} \cdot \mathrm{ha}^{-1} \mathrm{y}^{-1}$, $0.9 \mathrm{~kg} \cdot \mathrm{ha}^{-1} \mathrm{y}^{-1}$ and $1 \mathrm{~kg} \cdot \mathrm{ha}^{-1} \mathrm{y}^{-1}$ for $\mathrm{Mg}$ [18]. It may have increased slightly during the early regeneration period of the stand, but not enough to compensate for the losses.

The loss of 'base' cations and the reverse tendency of accumulation of $\mathrm{Al}^{3+}$ on the CEC, as well as the accumulation of $\mathrm{C}$, was typical of an acidification process, but with no major changes in the soil $\mathrm{pH}[13]$.

The high nitrification rate was probably the most active process of soil desaturation and weathering before and after the cutting, even if this rate decreased after the clearcutting $[25,26]$. All the nitrates produced and not taken up by the vegetation or immobilised by microbes gave a positive proton budget, immediately neutralised by the soil solid phase in ion-exchange or mineral weathering reactions. The changes in $\mathrm{K}$ were the greatest and were associated with a rapid and efficient $\mathrm{K}$-cycle. $\mathrm{K}$ is thought to undergo a cycle several times a year as it is not energetically-bound in organic molecules. Depletion of $\mathrm{K}$ was associated with the intense mineralisation of organic matter, and to the disruption of the biological cycle. Before the clear-cutting, the annual biological cycle had contributed about $10 \mathrm{~kg} \cdot \mathrm{ha}^{-1}$ through crown leaching and $7 \mathrm{~kg} \cdot \mathrm{ha}^{-1}$ through litter fall to the soil surface. This disruption led to a rapid desaturation of the CEC for an element whose retention in the soil strongly depends on the ion exchanger, in other words, specific efficient adsorption on vermicultetype sites [43] but low efficiency of organic sites [20]. The case for $\mathrm{Ca}$ and $\mathrm{Mg}$ was rather different. These elements were widely recycled mainly by litter fall $\left(22 \mathrm{~kg} \cdot \mathrm{ha}^{-1} \mathrm{y}^{-1}\right.$ for $\mathrm{Ca}$ and $2.3 \mathrm{~kg} \cdot \mathrm{ha}^{-1} \mathrm{y}^{-1}$ for $\mathrm{Mg}$ ), but their cycle was slower due to the limited role of crown leaching [40]. Ca, efficiently fixed by the soil organic exchange, tended to be retained, whereas $\mathrm{Mg}$, which was not as specifically adsorbed, was more sensitive to soil leaching [5]. Phosphorus, which has a very conservative cycle, just accumulates if mineralised.

Total changes showed that both the forest floor and the mineral soil changed but that changes in the forest floor were more extensive, except for P and K (Tab. VII).

\subsection{Reversibility of changes and relevance to soil functions}

Reversibility means that soil changes need to be related to the present available pool and that investigations have to be conducted on the long-term to control the dynamics of restoration processes. In the present study, the biogeochemical cycle 
Table VII. Summary of the quantitative soil changes three years after the clear-cutting.

\begin{tabular}{|c|c|c|c|c|c|c|}
\hline & $\mathrm{C}$ & $\mathrm{N}$ & $\mathrm{P}$ & $\mathrm{K}$ & $\mathrm{Ca}$ & $\mathrm{Mg}$ \\
\hline & \multicolumn{6}{|c|}{ kg.ha ${ }^{-1}$} \\
\hline Total content of the forest floor in 1998 & 16600 & 620 & 43 & 85 & 229 & 59 \\
\hline Mineral soil: available nutrient content in $1998(60 \mathrm{~cm})$ & & & 343 & 643 & 393 & 80 \\
\hline$\Delta(2001-1998):$ Forest-floor (1) & -10200 & -323 & -23 & -47 & -144 & -28 \\
\hline$\Delta(2001-1998):$ Mineral soil (2) & +5600 & -176 & +65 & -115 & -11 & -16 \\
\hline Total $(1)+(2)$ & -4600 & -499 & +42 & -162 & -155 & -44 \\
\hline
\end{tabular}

proved to be very efficient, but the active pool ensuring tree nutrition was quantitatively limited [38]. Consequently, stand development is a key factor for soil recovery.

The potential of soil mineral weathering to restore the current soil fertility in such an acidic soil is small and not linear because the most easily weatherable minerals have already disappeared. Potassium would certainly have recovered because the weathering flux was not that low (estimated at the site at $7.5 \mathrm{~kg} \cdot \mathrm{ha}^{-1} \mathrm{y}^{-1}$ by Ezzaïm, [18]), and its cycling was efficient and rapid when stand development reached canopy closure (at age 10). The depletion of Ca $(-25 \%$ of available reserves) and $\mathrm{Mg}(-32 \%$ of available reserves) are of the most concern because the soil reserves were very limited for these elements when compared to the threshold levels given by Bonneau [11]. Losses of $\mathrm{Ca}$ and $\mathrm{Mg}$ in such acidic soils are relevant because of their direct involvement in tree nutrition. However, it is more important to recognise that $\mathrm{Ca}$ is an efficient flocculent for soil aggregation and a catalyst for the activity of microorganisms. For $\mathrm{Ca}$ and $\mathrm{Mg}$, the potential of restoration of available reserves by mineral weathering was approximately $1 \mathrm{~kg} \cdot \mathrm{ha}^{-1} \mathrm{y}^{-1}$ [18]. The total atmospheric deposition compensates for part of this internal deficit but requires a developed stand to become significant (low fixation by ground vegetation). In the previous Douglas-fir stand, the total deposition was 8.7 and $1.3 \mathrm{~kg} \cdot \mathrm{ha}^{-1} \mathrm{y}^{-1}$, respectively for $\mathrm{Ca}$ and $\mathrm{Mg}$, among which 5.6 and $0.8 \mathrm{~kg} \cdot \mathrm{ha}^{-1} \mathrm{y}^{-1}$ were dry deposition caught by trees [40].

The cation exchange capacity (CEC), which measures cation retention in soils, was not modified after clear-cutting, indicating that the ion exchanger kept its characteristics, in other words, Al fixed on CEC did not polymerise, and SOM quality was not considerably altered.

Changes concerning soil organic matter $(\mathrm{C}, \mathrm{N})$ may be considered as reversible, as is usually the case in temperate climates. This is true except when drastic changes occur and, more particularly, if the soil remains bare for a long time or when land use changes. Organic $\mathrm{C}$ and $\mathrm{N}$ should recover with the development of the new stand. In the early stages, the development of $\mathrm{N}$-fixing species in the spontaneous vegetation, such as Cytisus scoparius (L.) Link., would probably compensate for part of the $\mathrm{N}$ losses. In 2004, it represented $10 \mathrm{t}$ of DM.ha ${ }^{-1}$, which contained $100 \mathrm{~kg}$ of $\mathrm{N}$, independently of $\mathrm{N}$ fixed and transferred to the soil (not measured). The same phenomenon occurred to some degree for the other nutrients temporarily stocked in the spontaneous vegetation.
In the present situation, losses by drainage did not greatly increase after clear-cutting and are therefore not able to completely explain the soil changes [39].

The young stage of the previous plantation was associated with high losses of cations resulting from excess nitrification [25]. If this had also occurred in the new plantation, serious losses in soil fertility would have been observed. Nevertheless, this was not necessarily the case because the new plantation did not take place on land abandoned by agriculture as in the first rotation, but instead replaced a previous Douglasfir stand. Further monitoring must be carried out in the coming years because the starting point for the new stand is now perfectly known and extrapolation from the previous rotation is uncertain.

In terms of soil production capacity, nutrient depletion corresponds to a decrease in availability, which does not necessarily lead to a decline in production. It depends on the absolute richness of the site and on the relationships between availability and crop response, which is unfortunately unknown for Douglas-fir in France. The requirements of Douglas-fir in terms of nutrients appear unlikely to lead to an immediate decline [50].

\subsection{A comparison of the present study to previously published results}

The impact of the clear-cutting of forest stands has been studied in many situations, especially in the United States. Results show that it tends to increase the rate of soil organic matter mineralisation [14] and often increases the nitrification rate [48] and, consequently, the leaching of nutrient cations out of the rooting zone [45]. Whole-tree harvesting tends to make soil reserves decrease more than stem-only harvesting, but it widely varies according to the situation. Carbon and, more generally, $\mathrm{N}$ are concerned in the upper soil layers $[33,44]$ but sometimes 'base cations' [23]. Slash treatment is important because slashes improve the soil organic reserves [21, 24, 47] and the nutrients, either fixed or not by soils [2], directly through mineralisation or indirectly through incorporation. Silvicutural practices such as strip-cutting decrease the negative impact of clear-cutting [15]. The control of understorey vegetation also has a strong effect on nutrient losses. Understorey acts as a buffer, retaining nutrients and preventing their leaching. Its complete and repeated eradication leads to intense mineralisation of the soil organic matter 
in most cases [44], and could increase the nitrification rate. It also leads to the leaching of nutrient cations [31].

The most commonly observed effects are short-term ones, whereas long-term trends generally remain speculative [2]. Simulation gave some indications as to the duration required for returning to pre-harvest levels. For example, Aber et al. [1] showed that up to 70 or 80 years were necessary for the forest floor to recover its $\mathrm{C}$ content.

It remains difficult to make general conclusion according to treatments and site characteristics. Soil nutrient depletion seems to be mainly determined by the length of time that the soil is left bare, but past land use has a major impact.

\section{CONCLUSION}

1. The hypothesis that low soil disturbance leads to small changes was not verified in the present study: changes were rapid and significant. The forest floor decreased and the mineral soil underwent a limited but real acidification. The changes demonstrated that the soil was in a dynamic equilibrium and was able to evolve rapidly with the environment. The changes in soil climate and the disruption of the biological cycle were the driving forces for changes [7]. The efficiency of the cycling processes to maintain alkaline and alkaline-earth cations in the upper layers of acidic soils was demonstrated once again.

2. In the present situation, 'base' cation desaturation, which is not reversible, is of some concern, as concluded from several indicators.

3. The wide spatial variability of soils, which required the use of a large number of samples in order to increase the accuracy of measurements and to obtain the smallest possible confidence intervals, proved to be the greatest difficulty, as mentioned above [22,51].

4. The duration of the impact of clear-cutting, the reversibility of changes, the cumulative effect of constraints and of their consequences on soil functions are all aspects that will remain speculative until long-term studies can be carried out [35]. In such an ecosystem where the effects of previous agricultural land use are still felt in terms of current soil function, it is impossible to directly extrapolate from the observations made on the early stage of development of the previous rotation to the new plantation situation [40]. The same situation occurs in the majority of high-yield plantations in France.

Acknowledgements: We would like to thank the forest managers from the French National Forestry Office and, in particular, Bernard Jobard for providing all the necessary facilities for this study, the GIPEcofor and the French Ministry of Ecology and Sustainable Development (GESSOL programme) for their financial support, and Gail Wagman for the English revision.

\section{REFERENCES}

[1] Aber J.D., Botkin D.B., Melillo J.M., Predicting the effects of different harvesting regimes on forest floor dynamics in northern hardwoods, Can. J. For. Res. 9 (1978) 10-14.
[2] Adams P.W., Boyle J.R., Soil fertility changes following clearcut and whole tree harvesting and burning in Central Michigan, Soil Sci. Soc. Am. J. 46 (1980) 638-640.

[3] Anne P., Sur le dosage rapide du carbone organique des sols, Ann. Agro. 2 (1945) 161-172.

[4] Badeau V., Dambrine E., Walter C., Propriétés des sols forestiers français : Résultats du premier inventaire systématique, Etud. Gest. Sols 6 (1999) 165-180.

[5] Baes A.U., Bloom P.R., Exchange of alkaline earth cations in soil organic matter, Soil Sci. 146 (1988) 6-14.

[6] Baize D., Girard M.C., Referentiel pédologique, INRA Paris, 1995, $332 \mathrm{p}$.

[7] Ballard T.M., Impacts of forest management on northern forest soils, For. Ecol. Manage. 133 (2000) 37-42.

[8] Bartlett R., James B., Studying dried, stored soil samples- Some pitfalls, Soil Sci. Soc. Am. J. 44 (1980) 721-724.

[9] Berthelin J., Leyval C., Toutain F., in: Bonneau M., Souchier B. Eds., Pédologie 2, Constituants et propriétés du sol, Chap. VII, Paris, 1994, pp. 142-237.

[10] Blake L., Goulding K.W.T., Mott C.J.B., Poulton P.R., Temporal changes in chemical properties of air-dried stored soils and their interpretation for long term experiments. Eur. J. Soil Sci. 51 (2000) 345-353.

[11] Bonneau M., La fertilisation des forêts dans les pays tempérés, Eds. ENGREF, Nancy (1995) 367 p.

[12] Bonneau M., Evolution of the mineral fertility of an acidic soil during a period of ten years in the Vosges mountains (France). Impact of humus mineralization, Ann. For. Sci. 62 (2005) 253-260.

[13] Van Breemen N., Mulder J., Driscoll C.T., Acidification and alkalinization of soil, Plant Soil 75 (1983) 283-308.

[14] Covington W.W., Changes in the forest floor organic matter and nutrient content following clear cutting in Northern hardwoods, Ecology 62 (1981) 41-48.

[15] Czapowskyj M.M., Rourke R.V., Frank R.M., Strip clear-cutting did not degrade the site in a spruce-fir forest in central Maine, USDA Forest Service Research Paper N-E 367 (1977) 1-8.

[16] Duchaufour P., Bonneau M., Une nouvelle méthode de dosage du phosphore assimilable dans les sols forestiers, Bull. AFES 4 (1959) 193-198.

[17] Dyck W.J., Cole D.W., Cromerford N.B., (Eds.), Impacts of forest harvesting on long-term site productivity, Chapman and Hall, 1994, $371 \mathrm{p}$.

[18] Ezzaïm A., Intérêt de la mesure du flux d'éléments issu de l'altération des minéraux des sols dans le calcul des bilans minéraux d'un écosystème forestier. Le cas des plantations de Douglas dans le Beaujolais (France), Thèse de doctorat de l'Université Henri Poincaré-Nancy I, 1997, 198 p. + annexes.

[19] François M., Étude de l'impact de la coupe rase d'une plantation de Douglas sur la fertilité chimique du sol, Mémoire de D.E.A. National de Science du Sol de 1'Université Henri Poincaré-Nancy I, Champenoux; Institut de la Recherche Agronomique de Nancy, 2000, 19 p.

[20] Gosz J.R., Likens G.E., Bormann F.H., Organic matter and nutrient dynamics of the forest floor in the Hubbard Brook forest, Oecologia 22 (1976) 305-320.

[21] Johnson C.E., Johnson A.H., Siccama T.G., Whole-tree clearcutting effects on soil horizons and organic matter pools, Soil. Sci. Am. J. 55 (1991) 497-502.

[22] Johnson C.E., Johnson A.H., Huntington T.G., Siccama T.G., Sample size requirements for the determination of changes in soil nutrient pools, Soil Sci. 150 (1990) 637-644.

[23] Johnson D.W., Kelly J.M, Swank W.T., Cole D.W, van Miegroet H., Hornbeck J.W., Pierce R.S., van Lear H., The effects of leaching and whole tree harvesting on cation budgets of several forests, J. Environ. Qual. 17 (1988) 418-424. 
[24] Jolivet C., Le carbone organique des sols des Landes de Gascogne. Variabilité spatiale et effets des pratiques agricoles et sylvicoles, Ph.D., Université de Bourgogne, 2000, 332 p.

[25] Jussy J.H., Colin-Belgrand M., Ranger J., Production and root uptake of mineral nitrogen in a chronosequence of Douglas-fir (Pseudotsuga menziesii (Mirb.) Franco) in the Beaujolais Mounts, For. Ecol. Manage. 128 (2000) 197-209.

[26] Jussy J.H., Ranger J., Bienaimé S., Dambrine E., Effects of a clearcut on the in situ nitrogen mineralisation and the nitrogen cycle in a 67-year-old Douglas-fir (Pseudotsuga menziesii (Mirb.) Franco) plantation, Ann. for. Sci. 61 (2004) 397-408.

[27] Legendre P., Legendre L., Numerical Ecology, 2nd English ed., Developments in Environmental Modelling, 20, Elsevier Science BV, Amsterdam, 1998, 863 p.

[28] Likens G.E., Bormann D.W., Pierce R.S., Reiners W.A., Recovery of a deforested ecosystem, Science 199 (1978) 92-496.

[29] Marques R., Ranger J., Nutrient dynamics in a chronosequence of Douglas-fir (Pseudotsuga menziesii (Mirb.) Franco) stands on the Beaujolais Mounts (France). 1: Qualitative approach, For. Ecol. Manage. 91 (1997) 255-277.

[30] Marshall V.G., Impacts of forest harvesting on biological processes in northern forest soils, For. Ecol. Manage. 91 (2000) 255-277.

[31] Munson A.D., Margolis H.A., Brand D.G., Intensive silvicultural treatment: impacts on soil fertility and planted conifer response, Soil Sci. Soc. Am. J. 57 (1993) 246-255.

[32] Nambiar E.K.S., Sustained productivity of forest is a continuing challenge to soil science, Soil Sci. Soc. Am. J. 60 (1996) 16291642 .

[33] Olsson B.A., Staaf H., Lundkvist H., Bengtsson J., Rosen K., Carbon and nitrogen in coniferous forest soils after clear-felling and harvests of different intensity, Forest Ecol. Manage. 82 (1996) 19-32.

[34] Pennock P.J., Van Kessel C., Clear-cut forest harvest impacts on soil quality indicators in the mixed-wood forest of Saskatchewan, Canada, Geoderma 75 (1997) 13-32.

[35] Poulton P.R., Management and modification procedures for longterm field experiments, Can. J. Plant Sci. 76 (1997) 587-594.

[36] Prescott C.E., Influence of clear-cutting and alternative silvicultural systems on rates of decomposition and nitrogen mineralisation in a coastal montane coniferous forest, For. Ecol. Manage. 61 (1997) $45-60$.

[37] Ranger J., Gelhaye D., Belowground biomass and nutrient content in a 47-year-old Douglas-fir plantation, Ann. For. Sci. 58 (2001) 423-430.

[38] Ranger J., Marques R., Colin-Belgrand M., Nutrient dynamics during the development of a Douglas-fir (Pseudotsuga menziesii Mirb.) stand, Acta Oecol. 18 (1997) 73-90.
[39] Ranger J., Loyer S., Gelhaye D., Pollier B., Bonnaud P., Effects of the clear-cutting of a Douglas-fir plantation (Pseudotsuga menziesii F.) on the chemical composition of soil solutions and on the leaching of DOC and ions in drainage waters, Ann. For. Sci. 64 (2007) 183-200.

[40] Ranger J., Allie S., Gelhaye D., Pollier B., Turpault M.P., Granier A., Nutrient budgets for a rotation of a Douglas-fir plantation in the Beaujolais (France) based on a chronosequence study, For. Ecol. Manage. 171 (2002) 3-16.

[41] Rouiller J., Guillet B., Bruckert S., Cations acides échangeables et acidités de surface. Approche analytique et incidence pédogénétique, Bull. AFES 2 (1980) 161-175.

[42] Roux F., Dynamique de la matière organique dans les sols sous peuplements résineux. Cas d'une parcelle de Douglas (Pseudotsuga menziesii (Mirb.) Franco) des Monts du Beaujolais ayant subi une coupe à blanc, Thèse Université de Bourgogne (2003), 210 p. + annexes.

[43] Shawney B.L., Selective sorption and fixation of cations by clay minerals: a review, Clays Clay Miner. 20 (1972) 93-100.

[44] Smethurst P.S., Nambiar E.K.S., Changes in soil carbon and nitrogen during the establishment of a second crop of Pinus radiata, For. Ecol. Manage. 73 (1995) 145-155.

[45] Snyder K.E., Harter R.D. Changes in solum chemistry following clear-cutting of northern hardwoods stands, Soil. Sci. Soc. Am. J. 49 (1985) 223-228.

[46] Stevenson F.J., Cycle of soil carbon, nitrogen, phosphorus, sulfur, micronutrients. Wiley-interscience publication, John Wiley \& Sons, NY, 1986, 380 p.

[47] Titus B.D., Malcolm D.C., Nutrient changes in peaty-gley soils after clear-cutting of Sitka spruce stands, Forestry 64 (1991) 251-269.

[48] Vitousek P.M., Matson P.A., Disturbance, nitrogen availability, and nitrogen losses in an intensively managed Loblolly pine plantation, Ecology 66 (1985) 1360-1376.

[49] Warckernagel H., Multivariate geostatistics, Springer Verlag, Berlin, 1995.

[50] Weissen F., (coord.), Le fichier écologique des essences. Tome 1 : texte explicatif, Tome 2 : le fichier écologique des essences, Ministère de la Région Wallonne, Direction générale des ressources naturelles et de l'environnement. Imprimerie Duculot Gembloux (Belgique), 1991.

[51] Yanaï R.D., Arthur M.A., Siccama T.G, Federer C.A., Challenges of measuring forest floor organic matter dynamics: repeated measures from a chronosequence, For. Ecol. Manage. 138 (2000) 273-283. 